\title{
Decentralization Matter of Healthcare and Effect on Regional Healthcare Efficiency: Evidence from Turkey'
}

Gökçe MANAVGAT (https://orcid.org/0000-0003-3729-835X), Department of International Trade and Logistics, Toros University, Turkey; e-mail: gokce.manavgat@toros.edu.tr

Ayhan DEMIRCI (https://orcid.org/0000-0003-3788-4586), Department of International Trade and Logistics, Toros University, Turkey; e-mail: ayhan.demirci@toros.edu.tr

\section{Sağlık Hizmetlerinde Yerinden Yönetimin Hizmet Performansı Üzerindeki Etkisi: Türkiye Örneği ${ }^{2}$}

\begin{abstract}
The aim of the current study is to examine the impact of regional decentralization model on the performance of public healthcare services in Turkey. The efficiency of public hospitals has been determined by the type of healthcare services, "general healthcare" and "oral-dental healthcare", with Data Envelopment Analysis at the level of 81 provinces (NUTS-3) for 2014 and 2017. By continuing the transition to decentralization in public health services, the possible effects on the regional health level were analyzed. Notably, this study employed conducted a two-dimensional analysis. First, public hospital performance at province level was determined. Second, it was investigated whether the decentralization of health services had a significant effect on the efficiency of bordering (contiguity) provinces, a measure taht captures spillover effects between performance scores. The results indicate that the efficiency scores of 81 province hospitals differ significantly according to the provision of service patterns. Moreover, the relative efficiency score in 2017 is found to be higher when compared 2014, which is the year that signifies the beginning of the decentralization shift in healthcare services in Turkey. Furthermore, there is a positive spatial spillover between public hospitals based on two types of hospital services. This means that the hospital efficiency in the contiguous province has an effect of increasing the efficiency score of the region. This suggests that the decentralization model in public health services may have the potential to create a positive impact on the general health level in the future if supported by progressive economic and health policies for developing countries such as Turkey.
\end{abstract}

Keywords

JEL Classification Codes : $\quad$ C14, I15, I18.
Efficiency, DEA, Public Healthcare, Public Hospitals, Spillover Effect, Decentralization.

\section{$\ddot{\mathbf{O} z}$}

$\mathrm{Bu}$ çalışmanın amacı, yerinden yönetim modelinin Türkiye'deki kamu sağlık hizmetlerinin performansı üzerindeki etkisini incelemektir. Kamu hastanelerinin etkinlikleri; 2014 ve 2017 yıllarına

1 The authors would like to thanks to Dr. Pierre Pecher from Aix-Marseille University, France, for his helpful suggestions and constructive comments.

2 Yazarlar, Aix-Marseille Üniversitesi'nden Dr. Pierre Pecher'e yararlı önerileri ve yapıcı yorumları için teşekkür ederler. 
ait veriler kullanılarak, 81 il düzeyinde (İBBS-3) "genel sağlık hizmetleri” ile "ağız ve diş hizmetleri” için Veri Zarflama Analiziyle belirlenmiştir. Sağlık hizmetlerinde yerinden yönetim modeline geçiş sürecinde hizmet etkinliğinin, bölgesel sağlık düzeyine olası etkileri analiz edilmiştir. Bu kapsamda çalışmada; öncelikle il düzeyinde kamu hastaneleri hizmet etkinlikleri belirlenmiş, ardından sağlık hizmetlerinde yerinden yönetim modelinin bölge sağlık düzeyi üzerinde bir etkisinin olup olmadığ1 incelenmiştir. Diğer bir ifadeyle, elde edilen etkinlik skorlarında mekânsal yayılma (spatial spillover) etkisi araştırılmıştır. Çalışma sonucunda belirlenen kamu hastaneleri etkinlik skorlarının sağlık hizmet sunumuna göre farklılık gösterdiği tespit edilmiştir. Yerinden yönetim uygulaması sonrasında, 2017 yılı, 2014 yılına göre göreli etkinlik skorlarında artış gözlenmiştir. Ayrıca her iki sağlık hizmeti bakımından kamu hastaneleri arasında pozitif mekânsal yayılmanın varlığına belirlenmiştir. Bu durum, bir ilin elde ettiği etkinlik skorunun, komşu illerin etkinlik skorlarından etkilendiğini ortaya koymaktadır. Dolayısıyla, sağlık hizmetlerinde yerinden yönetim modelinin, ilerici ekonomik ve sağlık politikalarıyla desteklenmesi halinde, sağlık düzeyi üzerinde olumlu bir etki yaratma potansiyeline sahip olduğu söylenebilir.

\section{Anahtar Sözcükler $\quad$ : $\quad$ Etkinlik, VZA, Sağlik Hizmeti, Kamu Hastaneleri, Mekânsal Etkileşim, Yerinden Yönetim.}

\section{Introduction}

Overgrown of the state by social welfare state implementations and due to the dramatic increases in public spending, countries' economic policies have been the focus of discussions on the neoliberal transformation, especially post-1980. In this process, the restructuring of the state and the redefinition of its role have begun to be debated, and public organizations have been reorganized in many countries. The state has been transformed from a service provider into a constructive, regulatory, supervisory and guiding structure and the market model has been trying to be placed in the public sector. Thus, the state has begun to be called by concepts such as "catalyst," "far-sighted," "decentralized" and "marketoriented" (Osborne \& Gaebler, 1993).

Efficiency and quality-oriented approaches have started in public service also in the health services. It is taken attention to the reorganization of regional structures in public health services. Besides the central management approach, the local power assignment has gained importance which responsible for local governments. It is called "decentralization" in the theory that share of power and responsibility for the services from the center to local (Costa-Font \& Turati, 2018). The most important reason for this motivation is the heterogeneous need for each region and responsibility for different preferential citizens (Oates, 1972). In addition, a structure that gives more importance to localization by moving away from the central bureaucracy; it is presented as a justification for the management understanding in the health services which will reduce costs by creating a competitive environment, contribute to productivity and effectiveness in a significant manner. Moreover, a structure that gives more importance to localization by moving away from the central bureaucracy is presented as a justification for a management approach in the health services which will reduce costs, create competitiveness, contribute to efficiency and effectiveness. 
Also, in Turkey, fundamental changes have occurred in the delivery of health services and understanding of the management of these services and regulations based on decentralization has been implemented. In 2003, "Health Transformation Program (HTP) was brought to the agenda and applied due to the weak and fragmented financing of healthcare, the barrier to access to health facilities and the lack of equity, the poor quality of healthcare and low level of health outcomes. HTP, which is put into practice within the framework of the agreement made with the World Bank, is designed by drawing attention to the ongoing structural problems in the Turkish health system $(\mathrm{MoH}, 2003)$.

HTP has been structured in three contexts of reforms that focus on the supply and financing of health services. The first change is in the structure of the social security system. Bag-Kur, SII and Retirement Fund, which covered different working groups in previous periods, were covered under a single scheme within the scope of Social Security Institution (SSI). Thus, SSI has become a monopsony in terms of social security funds, and the differences, obstacles, and constraints in the service utilities among insured have been reduced. Additionally, the transfer of SSI hospitals to the Ministry of Health has been provided with the distinction between the service provider and utilizer. Also, "Family Medicine Practice" has been passed in primary health care services, and services at this level have become free. Lastly, in 2011, Decree Law No. 663 on the Organization and Duties of the Ministry of Health and its Affiliated Institutions was issued. Thus, the organization, duties, powers, and responsibilities of the Ministry of Health $(\mathrm{MoH})$ and its affiliates have been rearranged. Thus, the organization, functions, powers, and responsibilities of the MoH and its members have been reorganized. Public Hospitals Association (PHA) was established in the Ministry of Health in accordance with the policies and objectives of the Ministry, to open, operate, monitor, evaluate and manage of the healthcare institutions. All kinds of preventive, diagnostic, therapeutic and rehabilitative health services in facilities affiliated to PHA are provided by MoH (Official Gazette, 2011).

Thus, the Public Hospitals Association (PHA) was established in 2012 in every province, and the public hospitals are autonomous depending on the central government. In this context, a more effective structure has been established in the determination of local health policies at the micro level. With this, effective understanding has been initiated to respond quickly to the health needs of the regions. Thus, the local thinking and holistic movement philosophy are taken as a basis in healthcare services (TKHK, 2012).

PHA structure has brought a new approach to the healthcare provider in Turkey. This new structuring to improve resource utilization and allocation is aimed at efficiency hospital service performance. The principle of "autonomous public hospitals" which is one of the methods applied in the scope of hospital reform studies, in theory, has been passed with PHA. It is ensured that hospitals are more efficient in terms of resource allocation in public hospital administrations. This is the most prominent feature of decentralization. Strengthening strategies in public hospital sector applications are such as the more flexible management approaches, the enhancement of authorities and responsibilities of managers, the suppression of overly repressive and supervisory behavior of central government units and the provision of community participation in hospital management boards (Harding \& 
Preker, 2003). Hence, hospital autonomy can be defined as the reduction of government control over public hospitals and the shifting of the decision-making mechanism from hospital to hospital hierarchy (Castano, 2004). In particular, it is suggested that in most developing countries, public hospitals consume a large proportion of their scarce health resources and that often the funds in question cannot be used effectively, which is why hospitals need urgent reform (Collins et al., 1999). On the one hand, it is also stated that local government-based hospital autonomy will increase inequalities in services subsidized by the public such as health care. Except for the central budget, the success of the hospitals in acquiring funding based on their management understanding affects the effectiveness of the service delivery directly and increases the disparities among regions. For this reason, it is essential that regional inequalities within the country are eliminated before this implementation (Giannoni \& Hitris, 2002; Ozcan \& Khushalani, 2017). Empirical results are debatable in studies about decentralization in a health system that increases the effectiveness of resource use and thus reduces regional disparities, but the study results are generally positive (Quadrado et al., 2001, Costa-Font \& Rico, 2006; Zhong, 2010) Political accountability, in the form of regional (legislative) autonomy, is deemed to increase the probability of health reforms (Chernichovsky, 1995), government spending and redistribution (Wigley \& Akkoyunlu-Wigley, 2011). On the other hand, if regional autonomy is reflected in regional-specific needs and preferences, the spatial distribution of resources should mirror such preferences, which would increase diversity in outputs. The success of decentralization depends on the differentiation of the institutional extensions of the policies that countries apply and the depth of imbalances in the socioeconomic structure (Costa-Font \& Turati, 2018).

On the other hand, in a concise period, PHA model has been the issue of abandonment in healthcare services since 2017 in Turkey as well. Although the name of the Hospital Association in the public sector has been changed as Hospital Headquarters, the decentralization philosophy in the functioning of the services continued to maintain its agenda in the provision of public health services. The effects of decentralization as discussed above, especially in countries with high regional disparities, the decentralization structure provides an improvement in inequality and improved efficiency. So, this study focuses on the importance of the continuity of implementation in the decentralization model.

Studies the model of decentralization in healthcare in Turkey is quite limited which examining the effects on the efficiency of hospital services and inequalities. While theoretical and political evaluations are important (Lamba et al., 2014), on the other hand, in the effectiveness analysis, it is seen that the PHA hospitals are examined in a whole understanding without leaving according to the service units (Küçük \& Şahin, 2015; Beylik et al., 2015; Yiğit, 2016; Atılgan, 2016, Şenol \& Gençtürk, 2017). No study analyses the ultimate effects on the regional health status on the decentralization of public hospitals.

The research object of the current study is to examine the impact of regional decentralization model on the performance of public healthcare services in Turkey. The efficiency of public hospitals (PHA) has been determined according to types of hospital service provision by using Data Envelopment Analysis (DEA) at the level of 81 provinces 
(NUTS-3) and in terms of regional decentralization. It was examined how healthcare service efficiency is affected regionally in the period after the establishment of Public Hospital Associations (PHAs). In the analysis, data from "Public Hospitals Statistics Yearbook 2014 and 2017" which is collected by Turkey MoH were employed to determine the efficiency score of two kinds of hospitals: one is General Healthcare, one is focused on Oral \& Dental Services. The transition period to decentralization in healthcare and the period after it was compared. The scores of each kind of hospitals were identified separately as "General Healthcare" and "Oral \& Dental Services," and efficient scores mapping was drafted. It has been determined that whether there is spatial integration (spillover) effect between the healthcare service between the provinces after the policy change as well. Thus, it was examined whether the decentralization of health services had a significant impact on the efficiency of neighboring (contiguity) provinces. If there is inter-province interaction in the health services activities of the provinces, the effect of this on the health level of the regions is also examined. In this context, the success of decentralization in raising the level of health, which is the goal of healthcare policy, has also been analyzed. In other words, the role of efficiency scores in affecting inequalities in the regional health level has been discussed by comparing two years.

\section{Empirical Strategy}

\subsection{Healthcare Efficiency: Data Envelopment Analysis}

In this section, we examine the main hypothesis of the paper, namely, whether decentralization in public healthcare services influences regional efficiency and whether there is spill-over effect on regional healthcare efficiency in terms of potential trigger for other (contiguity) province. We analysis that whether the efficiency of regional healthcare services reflect of regional health status. The starting point is to examine the decentralization of healthcare services in effect of services efficiency by using Data Envelopment Analysis (DEA).

Health care managers must adapt new methods to use the resources at their disposal in order to achieve high performance, namely effective and high-quality medical outcomes. Performance, as in other service industries, can be defined as an appropriate combination of efficiency and effectiveness. However, those frequently used terms, efficiency and effectiveness, are often used with a somewhat vague sense of meaning in the health care context. Efficiency generally refers to using the minimum number of inputs for a given number of outputs. Efficient care, therefore, means a health care facility produces a given level of care or quantity that meets an acceptable standard of quality, using the minimum combination of resources. In performance literature, efficiency and productivity are often used interchangeably. While productivity generally connotes a broader meaning, both terms are considered a component of performance. Effectiveness, more specifically, evaluates the outcomes of medical care and can be affected by efficiency or can influence efficiency as well as have an impact on the health service performance. For instance, effectiveness encourages us to ask if the necessary inputs are being used in order to produce the best 
possible outcomes. A hospital can be efficient, but not effective; it can also be effective, but not efficient. The aim is to be both (Ozcan, 2008: 4).

Data Envelopment Analysis (DEA) is a methodology based upon an interesting application of linear programming. It was originally developed for performance measurement. It has been successfully employed for assessing the relative performance of a set of firms that use a variety of identical inputs to produce a variety of identical outputs. The principles of DEA date back to Farrel (1957). The recent series of discussions on this topic started with the article by Charnes et al. (1978).

Data Envelopment Analysis (DEA) was accorded this name because of the way it "envelops" observations in order to identify a "frontier" that is used to evaluate observations representing the performances of all the entities that are to be evaluated. Uses of DEA have involved a wide range of different kinds of entities that include not only business firms but also government and non-profit agencies including schools, hospitals, military units, police forces and court and criminal justice systems as well as countries, regions, etc. The term "Decision Making Unit" (DMU) was therefore introduced to cover, in a flexible manner, any such entity, with each such entity to be evaluated as part of a collection that utilizes similar inputs to produce similar outputs. These evaluations result in a performance score that ranges between zero and unity and represents the "degree of efficiency" obtained by the thus evaluated entity. In arriving at these scores, DEA also identifies the sources and amounts of inefficiency in each input and output for every DMU. It also identifies the DMUs (located on the "efficiency frontier") that entered actively in arriving at these results. These evaluating entities are all efficient DMUs and hence can serve as benchmarks on route to effecting improvements in future performances of the thus evaluated DMUs (Cooper et al., 2006: XIX-XX).

Such evaluations take a variety of forms in customary analyses. Examples include cost per unit, profit per unit, satisfaction per unit, and so on, which are measures stated in the form of a ratio like the following (Cooper et al., 2002: 1);

$$
\text { Efficiency }=E=\frac{Y i}{X i}
$$

where the $\mathrm{E}$ is efficiency, $\mathrm{X}_{\mathrm{i}}$ inputs and $\mathrm{Y}_{\mathrm{i}}$ is outputs.

This is a commonly used measure of efficiency. But, it is not possible to have a single input and a single output environment. Today, many organizations are producing many and varied outputs, with a large number and with different units of measurement inputs. Therefore, the formula of simple activity is insufficient. Moreover, the weight of each input on the output is also important. In this case, the new activity formula has to be (Cooper et al., 2002: 21);

$$
\text { Virtual output / Virtual input }
$$

in case of 
Virtual input $=v_{1} x_{1 o}+v_{2} x_{2 o}+\cdots+v_{m} x_{m o}$

and

Virtual output $=u_{1} y_{1 o}+u_{2} y_{2 o}+\cdots+u_{s} y_{s o}$

Thus, the virtual input of a firm is obtained as the linear weighted sum of all its inputs;

$$
\text { Virtual Input }=\sum_{i=1}^{I} u_{i} x_{i}
$$

where ui is the weight assigned to input xi during the aggregation. Similarly, the virtual output of a firm is obtained as the linear weighted sum of all its outputs.

$$
\text { Virtual Output }=\sum_{j=1}^{J} v_{j} y_{j}
$$

where vj is the weight assigned to output yj during the aggregation. Given these virtual inputs and outputs, the Efficiency of the DMU in converting the inputs to outputs can be defined as the ratio of outputs to inputs.

$$
\text { Efficiency }=\frac{\text { Virtual Output }}{\text { Virtual Input }}=\frac{\sum_{j=1}^{J} v_{j} y_{j}}{\sum_{i=1}^{I} u_{i} x_{i}}
$$

Obviously, the most important issue at this stage is the assessment of weights. This is a tricky issue as there is no unique set of weights (Ramanathan, 2003: 38-39).

Recent years have seen a great variety of applications of DEA for use in evaluating the performances of many different kinds of entities engaged in many different activities in many different contexts in many different countries. One reason is that DEA has opened up possibilities for use in cases which have been resistant to other approaches because of the complex (often unknown) nature of the relations between the multiple inputs and multiple outputs involved in many of these activities (which are often reported in non-commeasurable units) (Cooper et al., 2002: XIX).

In literature there are two kinds of application of DEA. One of them is CCR model which is developed by Charnes, Cooper and Rhodes. CCR model is widely known as the constant returns-to-scale (CRS) model. The other one is BCC model which is developed by Banker, Charnes and Cooper. BCC model is known variable returns-to-scale (VRS) model, though in this model one cannot assume that scale of economy does not change as size of the service facility increases. Both models can be implemented as input-oriented and outputoriented and DEA applications have a lot of advantages in usage.

For model orientation, as in ratio analysis, when we calculate efficiency output over input, and place emphasis on reduction of inputs to improve efficiency, in DEA analysis this is called input-orientation. Input orientation assumes health care managers have more control over the inputs rather than arriving patients either for outpatient visit or admissions. However, the reverse argument can be made that the health care managers, through 
marketing, referrals or by other means (such as reputation on quality of services) can attract patients to their facilities. This means they can augment their outputs given their capacity of inputs to increase their organization's efficiency. Output augmentation to achieve efficiency in DEA is called output-orientation (Ozcan, 2008: 23; Khushalani \& Ozcan, 2017).

Before the using of DEA, we checked the dataset is normally distributed or not by using skewness kurtosis normality test. Our dataset generally has not normally distributed. Considering this situation, we used the basic frontier CCR and-input oriented model to compute efficiency of PHA services model, in paper. Since the examined hospitals are public hospitals, it is not the ultimate goal of this healthcare to increase the use of health facilities and services (i.e., operations, examination etc.). The increasing outputs is not considered as a goal for public hospital services. In a way, using of healthcare services more means that creating more patient, and that the health status is low. This is not preferable. Then for an input oriented and constant return to scale, form different inputs and s different outputs, the efficiency of decision making units can be measured by solving the following formulation (Demirci, 2018: 52);

$$
\begin{array}{lc}
\theta^{*}=\min \theta & \\
\text { s.t. } \\
\sum_{j=1}^{n} \lambda_{j} x_{i j} \leq \theta x_{i 0} & \mathrm{i}=1,2, \ldots, \mathrm{m} \\
\sum_{j=1}^{n} \lambda_{j} y_{r j} \geq y_{r 0} & \mathrm{r}=1,2, \ldots, \mathrm{s} \\
& \lambda_{j} \geq 0 \\
& \mathrm{j}=1,2, \ldots, \mathrm{n}
\end{array}
$$

\subsection{Sample, Input and Output Variables}

Measurement of the variables that describe the true nature of service production is an important prerequisite for performance measurement. In healthcare, due to the nature of the services provided, it is often difficult to find the appropriate variables and their measurements (Ozcan, 2008: 13; Ozcan \& Khushalani, 2017). Therefore, accurate measurement of outputs and inputs should be considered in measuring the efficiency of PHAs which based on decentralization. To define and measure the inputs and outputs at the hospital level, it is necessary to measure the service volume and scope of services provided by the hospitals. In this context appropriate adjustments have been undertaken to determine inputs and outputs. Firstly, in this study, hospitals have been separated to service units and defined determinant inputs and output variables in healthcare services.

Examining the model of decentralization on Turkey Public Hospitals Association (PHA) for the healthcare services, Public Hospitals Statistics Yearbook (PHSY) 2014 and 2017 data have been used $(\mathrm{MoH}, 2014 ; 2017)$. The healthcare service data in 2014 PHSY, was accepted as the beginning of the decentralization model. The healthcare service data in 2017 PHSY have been employed to show how the possible efficiency of the decentralization model could change. In both two data set, efficiency scores have been analysed for two 
different service units -"General Healthcare" and "Oral \& Dental Services"- at 81 provinces (NUTS-3) level.

Public Hospitals Statistical Yearbook (2014 and 2017) contains the first official data issued by the Ministry of Health after implication to PHA service model. Both hospital statistics yearbooks contain data that healthcare input and output which can be determined according to provincial level and different service units ${ }^{3}$. The point that is based to compute efficiency, the potential measurement variables (inputs and outputs) that reflect efficiency measuring and data set availability at the hospital level. Selected inputs and outputs to estimate the efficiency of two kind of healthcare services at the province level are in Table1.

Table: 1

\section{Variables Used in DEA}

\begin{tabular}{|c|c|c|c|}
\hline \multicolumn{4}{|c|}{ General Healthcare Services } \\
\hline \multicolumn{2}{|r|}{ Inputs } & \multicolumn{2}{|r|}{ Outputs } \\
\hline $\mathrm{X}_{\mathrm{ghl}}$ & Number of beds per 10.000 people & $\mathbf{Y}_{\mathrm{gh1}}$ & Number of examinations \\
\hline $\mathrm{X}_{\mathrm{gh} 2}$ & Intensive care beds per 10.000 people & $\mathbf{Y}_{\mathrm{gh} 2}$ & Total Birth- Parturition \\
\hline $\mathrm{X}_{\mathrm{gh} 3}$ & Number of physicians per 100.000 people & $\mathbf{Y}_{\mathrm{gh} 3}$ & Hospital bed turnover rate \\
\hline $\mathrm{X}_{\mathrm{gh} 4}$ & Nurse + midwife per 100.000 people & $\mathbf{Y}_{\mathrm{gh} 4}$ & Average length of hospital stay \\
\hline \multicolumn{4}{|c|}{ Oral \& Dental Services } \\
\hline & Inputs & & Outputs \\
\hline $\mathrm{X}_{\mathrm{od} 1}$ & Dentist (including specialist) & $Y_{\text {od1 }}$ & Tooth extraction per 1000 examinations \\
\hline $\mathrm{X}_{\mathrm{od} 2}$ & Unit per 7000 people & $\mathbf{Y}_{\text {od2 }}$ & Number of conservative treatments per 1000 examination \\
\hline $\mathrm{X}_{\mathrm{od} 3}$ & Number of polyclinics & $\mathbf{Y}_{\text {od3 }}$ & Endodontic treatments per 1000 examination \\
\hline
\end{tabular}

Inputs for general healthcare services include 4 variables (bed, intensive bed, physicians and nurse + midwife). Medical doctors and nurses, midwives and healthcare assistants are a proxy measure for the labor resources employed by the national healthcare system to deliver service, while the number of beds provides information on health care system capacities, i.e. capital resources used by the healthcare system (lo Storto \& Goncharuk, 2017: 107-8). Output include 4 variables (examination, birth, bed turnover and length of hospital stay). Inputs for oral and dental services include 3 variable (dentist, unit and polyclinics) and 3 outputs (tooth extraction, conservative treatments, endodontic treatments). These outputs that effectively provide measurements of benefits enjoyed by people, measures an "undesirable" or "bad output" of the health care system. Therefore, the bad output was treated as an input-oriented model in DEA. So the input orientation appears more suitable as hospitals can minimize their use of preventive resources in healthcare activities (Audibert et al., 2013).

3 In Hospitals Statistical Yearbook (2014), although there are 88 PHA operating in Turkey, three major provinces (Ankara, Istanbul and Izmir) PHA is divided into different regions. There are two in Ankara, six in Istanbul and two in İmir. However, the average healthcare data values of the PHAs operating in these three major provinces were considered in the study. However, such a distinction has not been made in the healthcare service data of three major provinces in 2017. 
Manavgat, G. \& A. Demirci (2020), "Decentralization Matter of Healthcare and Effect on Regional Healthcare Efficiency: Evidence from Turkey", Sosyoekonomi, Vol. 28(44), 261-282.

\section{Results}

The results of the study were evaluated in two stages. Firstly, efficiency scores that conduct with DEA results were assessed according to service units of PHAs and compared the efficiency score for 2014 and 2017, then the effect of spatial autocorrelation on efficiency scores between different regionals. Thus, the success of the efficiency scores on improving the health level due to inter-regional interaction has also been examined. In other words, it is calculated how an approach based on decentralization model is reflected in the efficiency scores of provinces. It was also analyzed whether the provinces with high-efficiency ratings showed a high health level. In this context, the role of the efficiency on the health level has been demonstrated.

\subsection{PHA Efficiency Scores and Frontiers}

Technical efficiency scores were calculated with the DEA approach under a constant return to scale and input-oriented model for PHA that operating in 81 provinces for 2014 and 2017 with Frontier Approach Package Program. Hospitals have been determined with efficiency scores of 100 that called full efficiency. The change in hospital efficiency scores between the two periods demonstrated. In Table 2 and 3, efficiency scores of hospitals in provinces were given by quantile range to summarize the results.

Accordingly, General Healthcare services in PHAs for 2014, Ağrı, Düzce, Elazı̆̆, Hakari, Mardin, Muş, Şanlıurfa, Şırnak, İstanbul, and Yalova are the reference hospitals that the full efficient service. Other words, only about $12,3 \%$ of PHAs provide service effectively for General Healthcare services in 2014. In 2017, which was accepted as the period after the transition to decentralization in healthcare, Ağrı, Bartın, Bursa, Düzce, Elazığ, Gaziantep, Kahramanmaraş, Kayseri, Kütahya, Osmaniye, Tekirdağ, and İstanbul are full efficient provinces. About $14,8 \%$ PHAs have an efficient score, and they are referenced. With decentralization number of full efficient public hospitals in the province increased. It is remarkable that generally relative efficient scores of hospitals have increased compared to 2014 (Table 2).

Table: 2

Technical Efficiency Scores for General Healthcare Service by Province

\begin{tabular}{|c|c|c|c|c|}
\hline \multicolumn{5}{|c|}{ General Healthcare } \\
\hline & \multicolumn{2}{|r|}{2014} & \multicolumn{2}{|r|}{2017} \\
\hline $\begin{array}{c}\text { Quantile } \\
\text { (Q) }\end{array}$ & $\begin{array}{c}\text { Efficiency } \\
\text { Scores }\end{array}$ & Provinces & $\begin{array}{c}\text { Efficiency } \\
\text { Scores }\end{array}$ & Provinces \\
\hline Q4 & $100-90.37$ & $\begin{array}{l}\text { Adana, Ağrı, Antalya, Bayburt, Düzce, Elazığ, } \\
\text { Gaziantep, Hakkari, Kastamonu, Kayseri, Kocaeli, } \\
\text { Mardin, Mersin, Muş, Şanlıurfa, Şırnak, Siirt, Van, } \\
\text { Yalova, İstanbul }\end{array}$ & $100-96.43$ & $\begin{array}{l}\text { Adana, Ağrı, Afyonkarahisar, Aksaray, Bartın, } \\
\text { Batman, Bursa, Düzce, Elazığ, Gaziantep, } \\
\text { Kahramanmaraş, Kayseri, Kocaeli, Kütahya, Manisa, } \\
\text { Niğde, Osmaniye, Şanlıurfa, Tekirdağ, İstanbul }\end{array}$ \\
\hline Q3 & $\begin{array}{l}89.73- \\
80.35\end{array}$ & $\begin{array}{l}\text { Afyonkarahisar, Balıkesir, Bartın, Batman, Bursa, } \\
\text { Çankırı, Diyarbakır, Erzurum, Hatay, } \\
\text { Kahramanmaraş, Kütahya, Malatya Manisa, Niğde, } \\
\text { Samsun, Tekirdağ, Tokat, Trabzon, Zonguldak }\end{array}$ & $93.1-85.76$ & $\begin{array}{l}\text { Antalya, Çankırı, Denizli, Diyarbakır, Eskişehir, } \\
\text { Hatay, Karaman, Kastamonu, Kırıkkale, Konya, } \\
\text { Mardin, Mersin, Nevşehir, Şırnak, Samsun, Siirt, } \\
\text { Trabzon, Van, Yalova }\end{array}$ \\
\hline Q2 & $\begin{array}{r}80.16- \\
69.28\end{array}$ & $\begin{array}{l}\text { Adıyaman, Bilecik, Bingöl, Bitlis, Çanakkale, } \\
\text { Çorum, Edirne, Erzincan, Eskiş̧ehir, Giresun, Iğdır, } \\
\text { Isparta, Kars, Kırıkkale, Konya, Muğla, Nevşehir, } \\
\text { Osmaniye, Sivas, Tunceli, İzmir }\end{array}$ & $84.76-73.13$ & $\begin{array}{l}\text { Adıyaman, Aydın, Balıkesir, Bilecik, Çanakkale, } \\
\text { Çorum, Edirne, Gümüşhane, Giresun, Hakkari, Iğdır, } \\
\text { Isparta, Kars, Kırklareli, Malatya, Muğla, Sakarya } \\
\text { Sivas, Tokat, İzmir }\end{array}$ \\
\hline
\end{tabular}




\begin{tabular}{|c|c|c|c|c|}
\hline Q1 & $\begin{array}{l}67.75- \\
44.85\end{array}$ & $\begin{array}{l}\text { Aksaray, Amasya, Ankara, Ardahan, Artvin, Aydın, } \\
\text { Bolu, Burdur, Denizli, Gümüşhane, Karabük, } \\
\text { Karaman, Kırklareli, Kırşehir, Kilis, Ordu, Rize, } \\
\text { Sakarya, Sinop, Uşak, Yozgat }\end{array}$ & $\begin{array}{l}68.35- \\
42.38\end{array}$ & $\begin{array}{l}\text { Amasya, Ankara, Ardahan, Artvin, Bayburt, Bolu, } \\
\text { Burdur, Bingöl, Bitlis, Erzurum, Erzincan, Karabük, } \\
\text { Kirşehir, Kilis, Muş, Ordu, Rize, Sinop, Tunceli, } \\
\text { Uşak, Yozgat }\end{array}$ \\
\hline
\end{tabular}

The PHAs hospitals that service in Oral \& Dental healthcare; Adana, Ardahan, Bayburt, Gaziantep, Hakkari, Mardin, Mersin, Şanlıurfa, Tunceli and Van are the reference hospitals that the full efficient service. PHAs, which is fully effective in Oral \& Dental healthcare, constitutes $12.3 \%$ of the total. In 2017, Ağr1, Ardahan, Batman, Bayburt, Diyabakır, Hakkari, Mardin, Muş, Şırnak ve Tunceli was full efficient provinces among public hospitals. The number of efficient hospitals in provinces is the same according to 2014. Besides, relative efficiency scores of Oral \& Dental healthcare services are lower than those of General Healthcare services (Table 3).

Table: 3

Technical Efficiency Scores for General Healthcare Service by Province

\begin{tabular}{|c|c|c|c|c|}
\hline \multicolumn{5}{|c|}{ Oral \& Dental Healthcare } \\
\hline \multicolumn{3}{|r|}{ Oi ail o bentai in } & \multicolumn{2}{|r|}{2017} \\
\hline $\begin{array}{c}\text { Quantile } \\
\text { (Q) }\end{array}$ & $\begin{array}{c}\text { Efficiency } \\
\text { Scores }\end{array}$ & Provinces & $\begin{array}{c}\text { Efficiency } \\
\text { Scores }\end{array}$ & Provinces \\
\hline Q4 & $100-75.87$ & $\begin{array}{l}\text { Adana, Ağrı, Antalya, Ardahan, Bayburt, Bitlis, } \\
\text { Erzincan, Gaziantep, Hakkari, İstanbul, Kayseri, } \\
\text { Malatya, Mardin, Mersin, Siirt, Şanlıurfa, Şırnak, } \\
\text { Trabzon, Tunceli, Van }\end{array}$ & $100-82.91$ & $\begin{array}{l}\text { Adana, Ağrı, Afyonkarahisar, Ardahan, Bartın, } \\
\text { Batman, Bayburt, Bingöl, Bitlis, Diyarbakır, } \\
\text { Hakkâri, Hatay, Kars, Mardin, Muş Şanlıurfa, } \\
\text { Şırnak, Tunceli, Van } \\
\end{array}$ \\
\hline Q3 & $73.38-59.81$ & $\begin{array}{l}\text { Afyonkarahisar, Bartın, Batman, Bingöl, Bursa, } \\
\text { Diyarbakır, Hatay, İzmir, Kahramanmaraş, Kars, } \\
\text { Kırıkkale, Konya, Kütahya, Muğla, Muş, Ordu, } \\
\text { Sakarya, Tekirdağ, Uşak, Yalova } \\
\end{array}$ & $82.3-70.14$ & $\begin{array}{l}\text { Aksaray, Antalya, Aydın, Bursa, Düzce, Erzurum, } \\
\text { Gaziantep, Giresun, Iğdır, İstanbul, Kahramanmaraş, } \\
\text { Kayseri, Kilis, Kütahya, Malatya, Niğde, Ordu, } \\
\text { Osmaniye, Siirt, Uşak }\end{array}$ \\
\hline Q2 & $59-78-48.98$ & $\begin{array}{l}\text { Aksaray, Ankara, Arvin, Aydın, Balıkesir, Burdur, } \\
\text { Çorum, Denizli, Düzce, Erzurum, Giresun, } \\
\text { Gümüşhane, Iğdır, Kırklareli, Kırşehir, Kocaeli, } \\
\text { Nevşehir, Osmaniye, Tekirdağ, Zonguldak }\end{array}$ & $61.75-55.05$ & $\begin{array}{l}\text { Adıyaman Artvin, Balıkesir, Burdur, Çorum, Elazı̆̆, } \\
\text { Erzincan, Gümüşhane, Karaman, Kastamonu, } \\
\text { Kocaeli, Konya, Muğla, Nevşehir, Sakarya, Tokat, } \\
\text { Trabzon, Yalova, Yozgat, Zonguldak }\end{array}$ \\
\hline Q1 & $48.76-34.83$ & $\begin{array}{l}\text { Adıyaman, Amasya, Bilecik, Bolu, Çanakkale, } \\
\text { Çankırı, Edirne, Elazı̆̆, Eskişehir, Isparta, Karabük, } \\
\text { Karaman, Kastamonu, Kilis, Manisa Niğde, Rize, } \\
\text { Samsun, Sinop, Sivas, Yozgat }\end{array}$ & $54.12-42.84$ & $\begin{array}{l}\text { Amasya, Ankara, Bilecik, Bolu, Çanakkale, Çankırı, } \\
\text { Denizli, Edirne, Eskişehir, Isparta, İzmir, Karabük, } \\
\text { Kırıkkale, Kırşehir, Manisa, Rize, Samsun, Sinop, } \\
\text { Tekirdağ }\end{array}$ \\
\hline
\end{tabular}




\section{Figure: 1}

\section{Efficiency frontier for General Healthcare 2014-2017}
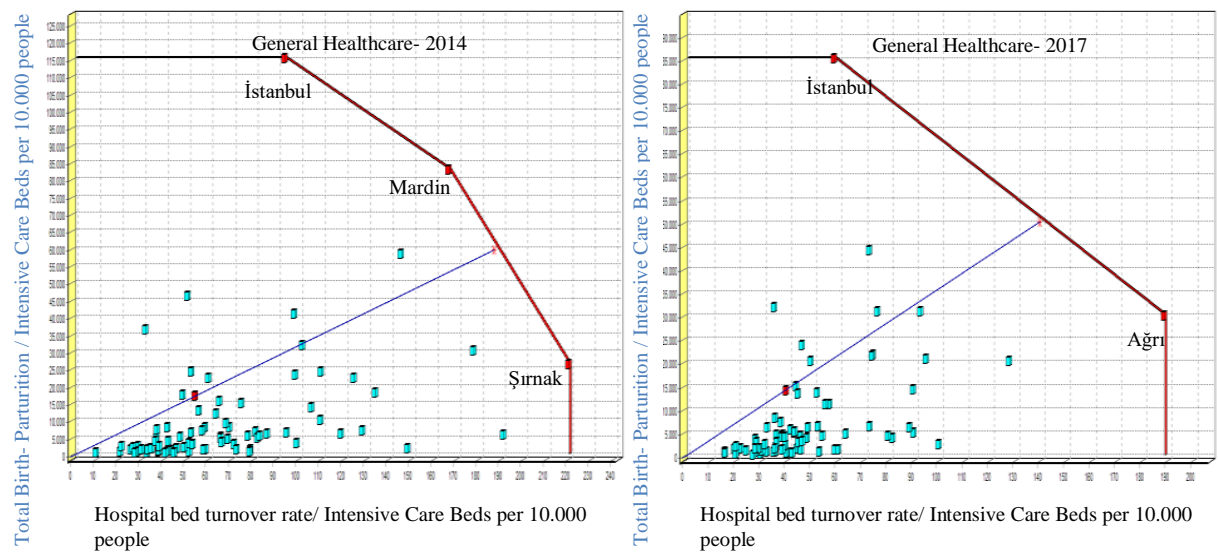

And also, to investigate the frontiers, we employed one input (intensive care bed per 10.000 people) and two outputs (hospital bed turnover and total birth) which are the most significant weight among variables at efficiency scores. Figure 1 shows conceptualization of constant returns and associated frontier for General Healthcare in 2014 and 2017. Here İstanbul, Mardin and Şırnak define the different parts of frontier for 2014 and İstanbul and Ağrı define the different parts of frontier for 2017.

Similarly, Figure 2 shows conceptualization of constant returns and associated frontier for Oral \& Dental Healthcare in 2014 and 2017. We use one input (units per 7000 people) and two outputs (Endodontic treatments per 1000 and tooth extraction per 1000 examinations), because these variables has more significant on efficiency scores. As can be observed, there are three provinces, Mardin, Şırnak and Gaziantep in 2014 and Batman, Şırnak, Diyarbakır in 2017, that fall on the boundaries drawn. These provinces represent the efficiency frontier and they are among the benchmark province for Oral \& Dental Healthcare. 


\section{Figure: 2}

\section{Efficiency frontier for Oral \& Dental Healthcare 2014-2017}

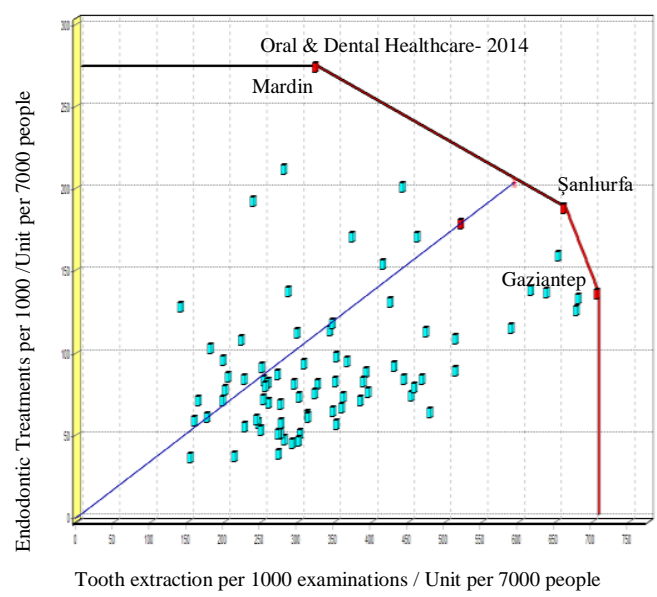

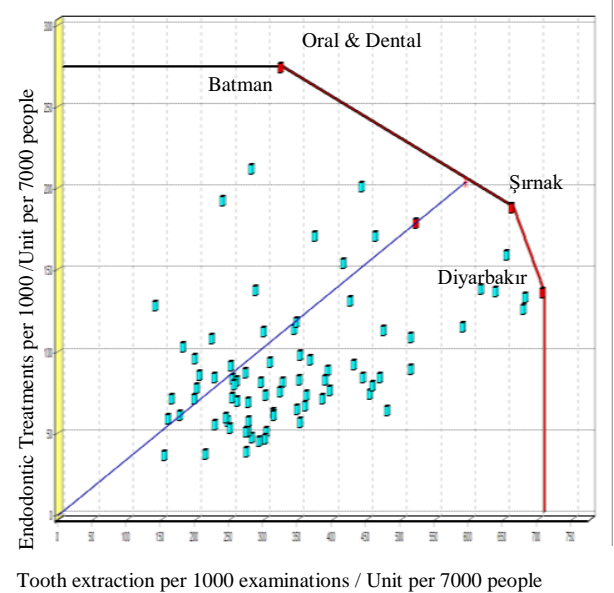

In terms of efficiency scores, it is noteworthy that the PHAs in the provinces with relatively high efficiency are mostly in the south and eastern Anatolia regions in both years and regions with less regional development. At this point, it is observed that policy implementation based on decentralization in hospital services has a positive effect on efficiency in the development of regional health level. On the other hand, assuming that the health service provided by the PHAs serving in the underdeveloped regions in terms of economic development is similar to those in other regions, it also raises a different interpretation of the results. As a matter of fact, in most of these hospitals, there is no similar equipment to provide treatment for diseases, so the severity of illness and patient applications are not homogeneous. In this case, it should be considered that the hospitals with fully equipped and high case complications have lower efficiency scores. Therefore, it should be taken into consideration case that the regions where the service capacity and severity of illness is high seems inefficient. That's why it is not adequate to use the efficiency score analysis as a single method in evaluating the policy goal based on the decentralization health service approach. It should be considered the possible effects of PHAs with highefficiency scores on regional health status.

\subsection{PHA Regional Efficiency Score Maps and Health Level}

There have been considerable improvements since the past, at the point of eliminating inter-regional economic and social imbalances in Tukey. But even if it is observed that there are differences especially in terms of health service provision and health outcomes. In this context, it is expected that PHA as a model of local governance in the decentralization of health services will provide significant contributions to improve health care performance and improve health status in underdeveloped regions. In priority regions for development in 
Turkey (e.g., in the Eastern, south-eastern and Eastern Black Sea regions), to become a more accessible and efficient provision of healthcare services and the quality are the main reasons of healthcare reforms. In this regard, based on efficiency scores from DEA, it is accepted that this model of hospital management understanding will be an effective regulation as long as the contribution of the efficiency of PHA hospital service on health outcomes increases. When the two years were compared, it was seen that efficiency scores increased especially in general healthcare services.

The mapping of the efficiency scores of PHA's hospital services has been drafted across the regions. Thus, it was pointed that whether there might be an interaction (spillover) between interregional efficiency scores. Furthermore, the effect of hospital performance efficiency score on health level between regions was analyzed.

Firstly, the efficiency scores of the PHA of provinces based on data envelopment analysis (DEA) were mapped. Then, the existence of the spatial autocorrelation (spatial dependence) between these efficiency scores was examined by using Moran's I Test statistic. To test the presence of the spatial autocorrelation, spatial weight matrix $\left(\mathrm{w}_{\mathrm{i}, \mathrm{j}}\right)$ was created at $81 * 81$ level based on queen contiguity. If provinces are a bounder, it is coded as 1 , otherwise 0 .

Moran's I measures spatial autocorrelation based on both feature locations and feature values simultaneously. Given a set of features and an associated attribute, it evaluates whether the pattern expressed is clustered, dispersed, or random. The tool calculates the Moran's I statistic value and both a z-score and p-value to assess the significance of that Moran's I. P-values are numerical approximations of the area under the curve for a known distribution, limited by the test statistic (Anselin, 1988).

Moran's I statistic for spatial autocorrelation is given as:

$$
I=\frac{n}{S_{0}} \frac{\sum_{i=1}^{n} \sum_{j=1}^{n} w_{i, j} z_{i} z_{j}}{\sum_{i=1}^{n} z_{i}^{2}}
$$

where $\mathrm{z}_{\mathrm{i}}$ is the deviation of an attribute for feature $i$ from its mean $\left(\mathrm{x}_{\mathrm{i}}-\mathrm{X}\right), \mathrm{w}_{\mathrm{i} . \mathrm{j}}$ is spatial weight matrix between feature (province) $i$ and $j, n$ is equal to the total number of features and $S_{0}$ is aggregate of all spatial weights:

$$
S_{0}=\sum_{i=1}^{n} \sum_{j=1}^{n} w_{i, j}
$$

ZI - score for the statistic is computed as:

$$
Z_{l}=\frac{I-E[I]}{\sqrt{V[I]}}
$$

where:

$$
E[I]=-1(n-1)
$$




$$
V[I]=E\left[I^{2}\right]-E[I]^{2}
$$

Moran's I statistic; the null hypothesis states that the attribute being analyzed is randomly distributed among the features in your study area; said another way, the spatial processes promoting the observed pattern of values is random chance. It may stress that Moran's I close connection to the common Durbin Watson test. Moran's I was not developed with any specific kind of dependence as the alternative hypothesis, although it has been found to have power against a wide range of forms of spatial dependence (Anselin \& Bera, 1998: 265).

In Figure 3, the efficiency performances of General Healthcare are analyzed with the assumption of CCR and mapping is done with this assumption for 2014 and 2017. According to this, it is seen that the PHAs with high relative efficiency score or full efficiency scores are in the contiguous (neighbour). The regions where the efficiency score is high are part of the Southeast Anatolia, Eastern Anatolia and Central Anatolia regions. In General Healthcare, the region with the lowest efficiency score of PHAs are in the central and eastern Black Sea. The notable point on the map is that the high score for the PHAs General Healthcare is also high for in the contiguous (neighbor) region or vice-versa. Moran's I test statistic which based on spatial autocorrelation with the contiguity matrix $(81 * 81)$ has been computed to test its spatial significant or not. For 2014 and 2016 respectively, Morans' $\mathrm{I}=0.1419(\mathrm{p}=0.0270, \mathrm{z}=2.118)$ and Morans' $\mathrm{I}=0.1361(\mathrm{p}=0.0300, \mathrm{z}=2.0346)$ so we may reject the null hypothesis. The spatial distribution of high values and low values in the efficiency scores are more spatially clustered or not spatial processes random. It means that there is a positive spill-over effect inter-regional efficiency score of PHAs in services General Healthcare. It means that there is a positive spillover effect inter-regional efficiency score of PHAs. There is a positive spill-over among the General Healthcare of PHA performance efficiency scores. This situation is shown in the scatter diagram. Try to avoid unclear antecedent.

The distribution of efficiency scores for Oral \& Dental Health Services is based on a constant return to scale assumption is shown in Figure 4. There is a similar situation in General Healthcare in terms of efficiency scores mapping. The high score for the PHAs Oral $\&$ Dental services is also high for in the contiguous region or vice-versa. It is shown in the scatter diagram as well and statistically significant. For 2014 and 2016 respectively, Morans' $\mathrm{I}=0.2079$ ( $\mathrm{p}=0.0060, \mathrm{z}=3.0418)$, Morans' $\mathrm{I}=0.4288$ ( $\mathrm{p}=0.0010, \mathrm{z}=6.2956)$. It means that there is a positive spillover effect inter-regional efficiency score of PHAs. There is a positive spillover among the General Healthcare of PHA performance efficiency scores. The effect of spatial interaction between efficiency scores in Oral \& Dental services is higher than that of General healthcare services in terms of Moran's I statistic value. 
Figure: 3

\section{General Healthcare Services Efficiency and Regional Contiguity by Province}
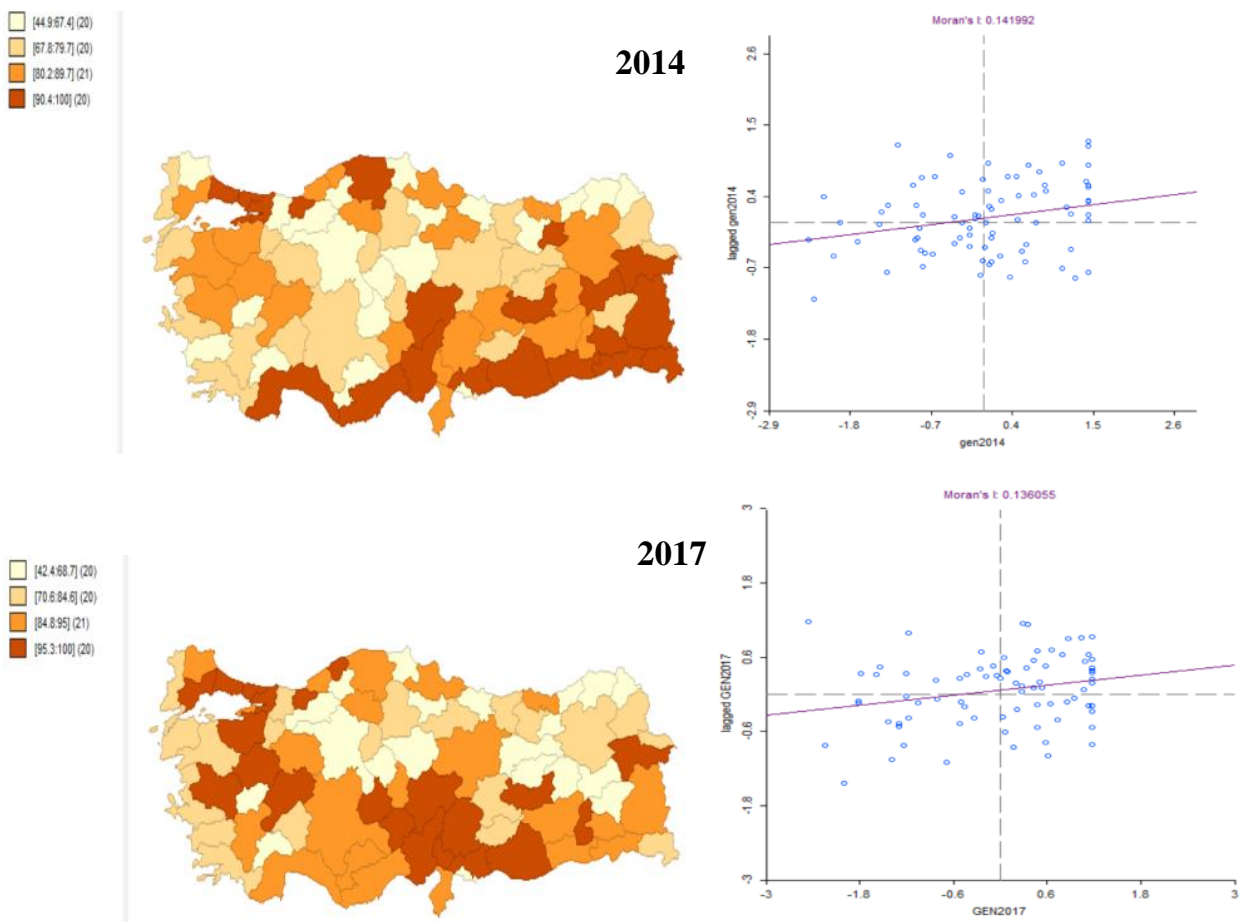

In general, the full or high-efficiency scores are in regions where the least developed and have low health status in Turkey. In other words, efficiency scores are high in regions relative low health level. It seems to be a contradiction, but it is not a measurement problem. The inter-regional hospital services are not similar quality. The cause of these results; public hospitals servicing the region are not qualified to treat the diseases of similar complexity or not similarly equipped for servicing of disease important. Therefore, it can be considered that relative efficiency scores to be high for an inhomogeneous regional development.

Nevertheless, in addition to this thought, there is the potential to increase health levels due to the high level of efficiency scores in the less developed and low-health regions and the externality effect that exists between public health services. Because the efficiency scores of public health services among provinces are not exclusivity, but complementarity and this effect increase according to the previous period as well. This suggests that the decentralization model in public health services has the potential to create positive effects on the health level in the future if supported by progressive economic and health policies. 


\section{Figure: 4}

\section{Oral \& Dental Services Efficiency and Regional Contiguity by Province}

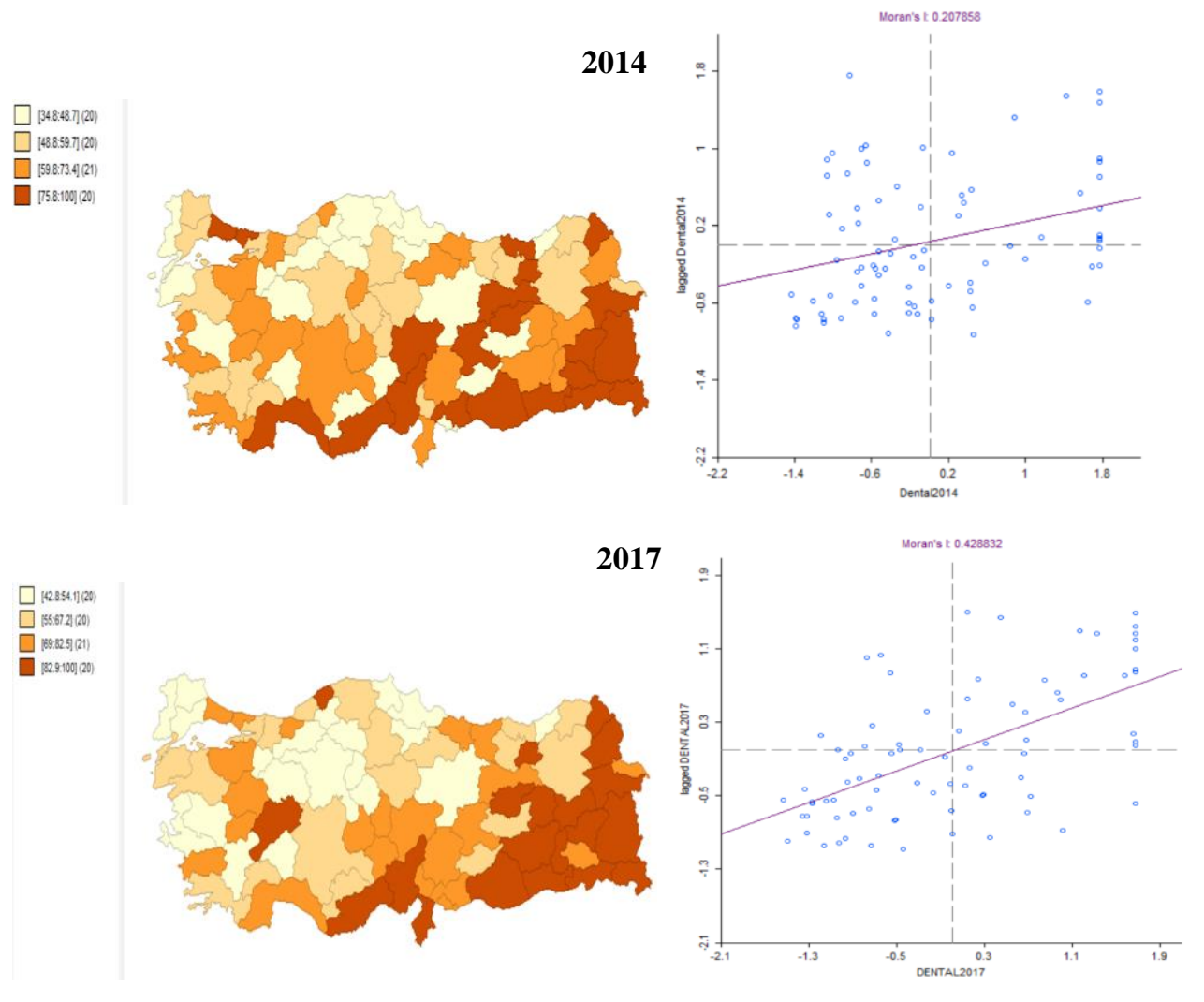

We used simple correlation analysis to observe the relationship between hospital efficiency scores and health level. Thus, the effect of efficiency scores obtained at 81 provinces (NUTS-3) was examined on a regional level of health. The life expectancy at birth, birth rates, maternal mortality, and infant mortality rate (perinatal-neonatal mortality) are widely used variables. However, the infant mortality rate is considered to be one of the most critical and comparable variables of health status. So, the infant mortality rate ${ }^{4}$ for provinces was accepted as a health level indicator (WHO, 2017; Joumard et al., 2008).

The relationship between infant mortality rate and General Healthcare efficiency score have been analyzed for 2014 and 2017. The simple correlation between them is shown 
in scatter diagrams. Accordingly, the higher the efficiency score of hospitals, on the one hand, the higher the infant mortality rate on that for 2014. Contrary to expectations, as the hospital efficiency score increases, the level of health in regions declines. Although the effect of the decentralization policy on efficiency is high in the less developed regions, it does not positively affect the level of health. For 2017, the correlation between public hospital efficiency scores and regional health level is in the expected direction, but it is not statistically significant (Figure 5).

Figure: 5

\section{Infant Mortality Rate and Hospital Efficiency Scores (2014-2017)}
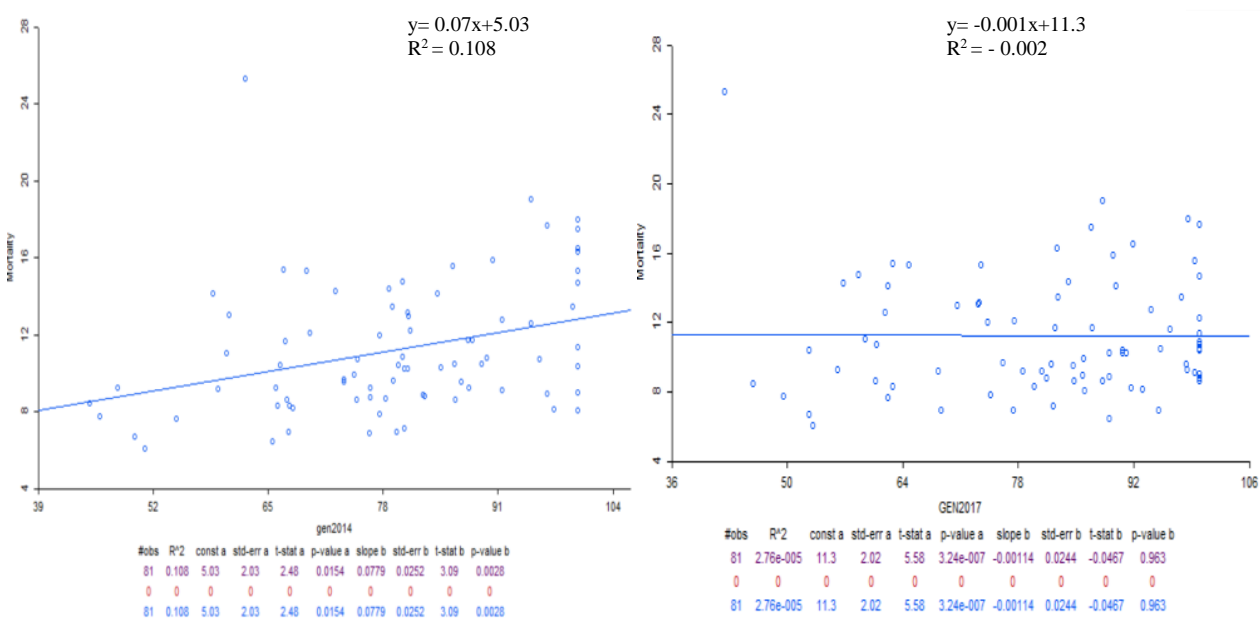

Last, the effect of the efficiency score of public healthcare services in General Healthcare on the health status of the province has been examined by employing a spatial lag model. The infant mortality rate was used as a health level indicator and explanatory variable. The estimated spatial lag model coefficients $(\beta)$ are in Table 4. It shows that the efficiency scores are positively and statistically significant on infant mortality rates in 2014 and 2017. The health level of the provinces is not only a variable that explains the hospital efficiency scores, but also the health level of the regions depending on the neighborhood relationship. In the model, the infant mortality rate is affected positively by the infant mortality rate in the neighboring region and the coefficient is statistically significant for both years (w*infant mortality: 0.706 and 0.740 ). The improvement in the health level of a province is to bring out positive externality over the other contiguous province.

Table: 4

\section{Spatial Regression Estimation for Efficiency Scores and Infant Mortality Rate}




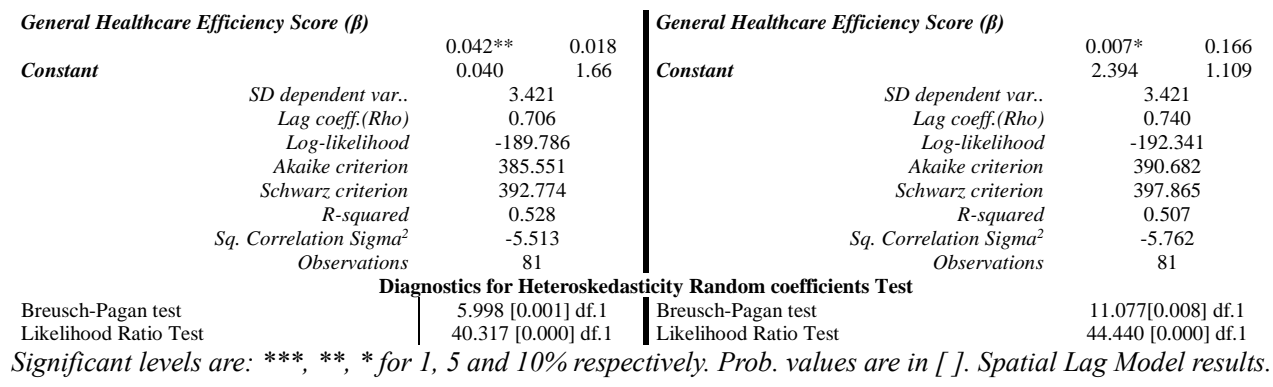

\section{Conclusion}

Of all public services, healthcare has been the most commonly decentralized responsibility to regional governments in Turkey like Europe and stands as the main and growing share of regional budgets. That is, in the past decades we have envisaged a progressive reallocation of health system authority as well as fiscal responsibilities to subcentral managements. The Public Hospitals Association model initiated such a transformation of the healthcare system in Turkey. The impact of the decentralization approach on regional development and service quality in the healthcare provision model has begun to take place in the study of health economists and health managers. From all of this, whether decentralization effects healthcare services efficiency and regional health level is an empirical question and the main aim of this paper.

In Turkey, we have examined evidence from PHA model and which have decentralized the management of the health system in hospital efficiency. Notably, we have investigated whether decentralization has led to regional imbalances in health level or outcome. First, we have analyzed the PHA efficiency scores for two type of service units which is General Healthcare and Oral \& Dental Services by using DEA For this, we used 2014 and 2017 dataset. The healthcare service data in 2014 was accepted as the beginning of the decentralization model. The healthcare service data in 2017 was employed to show how the possible effects of the decentralization model could change. Thus, we compared the efficiency score of public hospital services. And then we have investigated the relationship between decentralization-based service efficiency of public healthcare services and health status at the level of 81 provinces (NUTS-3). In examining this, we also considered the effect of spatial spillover that considers the efficiency of hospital service in a region on hospital efficiency in the contiguous region.

The efficiency scores obtained for both two types of service unit base on constant return to scale and input-oriented model. For General Healthcare services in 2014 and 2017, $12.3 \%$ and $14.8 \%$ of public hospitals in 81 provinces are full efficient respectively. With decentralization number of full efficient public hospitals in the province increased. It is remarkable that generally relative efficient scores of hospitals have increased compared to 2014. For Oral \& Dental services efficiency scores in both two years, public hospitals of $12.3 \%$ are fully efficient. Regionally, it has been determined that the most effective public hospitals in General Health Care and Oral \& Dental Services are located in the East and 
Southeast part of Turkey, where the regions with the lowest socio-economic development. At this point, it has been observed that policy implementation based on decentralization in hospital services has a positive effect on efficiency in the development of regional health level.

On the other hand, in the study, the relationship between hospital efficiency scores and regional health outcome was investigated at the level of 81 provinces. According to this, we accepted that infant mortality rate as a health level (outcome) indicator in territories. There is a positive spatial spillover between every two types of hospital service provenance unit among public hospitals. This means that the hospital efficiency in the contiguous province has an effect of increasing the efficiency score of the province. This suggests that the decentralization model in public health services has the potential tool to create positive effects on the health level in the future if supported by progressive economic and health policies. But for now, contrary to expectations, the regions have low health status where the hospital efficiency score is relatively high. In other words, the high-efficiency score does not reflect the desired high health level in the region. When the hospital efficiency score increases in public hospital services, the level of health in regions decrease.

From all of these, it is too early to predict that the decentralized health service model that the first attempt is called PHA can affect positive contribution to healthcare delivery. However, it is clear that efficiency of public healthcare services is not competitive due to positive spatial spillover, so complementary in service provision between PHAs might be a significant factor to reduce of the regional health disparities more quickly. The challenge lies in how to maintain a balance between incentivizing policy innovation and diffusion without hampering spatial cohesion for health services.

To conclude, public hospital services efficiency is high where the socio-economically disadvantaged region in Turkey. On the other hand, results from this short-term analysis, even if efficiency scores were not found at the intended level to reflect the health outcome of the regions, some findings have the potential to raise the level of health in this study. It should be noted that the shift to a decentralized hospital management model of regional health services is a relatively new discussion in Turkey. The effects of reforms and arrangements in the area of health need to be examined in the long term. Therefore, it is clear that the expected effect will contribute more to the regions if the hospital efficiency scores in relatively less developed regions in health services are carried out together with supportive policies to raise the health level.

\section{References}

Anselin, L. \& A.K. Bera (1998), "Spatial Dependence in Linear Regression Models with an Introduction to Spatial Econometrics", in: A. Ullah \& D.E.A. Giles (eds.), Handbook of Applied Economic Statistics, Marcel Dekker, NY., 237-289.

Anselin, L. (1988), Spatial Econometrics: Methods and Models, Kluwer, Boston, London, Academic Publishers. 
Atılgan, E. (2016), “Kamu Hastaneleri Birlikleri Performans Ölçüm Yöntemi Üzerine Bir Değerlendirme", Journal of Human Sciences, 13(1), 695-712.

Audibert, M. \& J. Mathonnat \& A. Pelissier \& X.X. Huang \& A. Ma (2013), "Health Insurance Reform and Efficiency of Township Hospitals in Rural China: An Analysis from Survey Data", China Economic Review, 27, 326-338.

Beylik, U. \& H.İ. Kayral \& Ü. Naldöken (2015), "Sağlık Hizmet Etkinliği Açısından Kamu Hastane Birlikleri Performans Analizi”, C.Ü. Sosyal Bilimler Dergisi, 39(2), 203-224.

Castano, R. \& R. Bitran \& U. Giedion (2004), Monitoring and Evaluating Hospital Autonomization and Its Effects on Priority Health Services, Partners for Health Reform plus, <http://www.phrplus.org/Pubs/Tech052_fin.pdf>, 25.01.2019.

Chernichovsky, D. (1995), "Health System Reforms in Industrialized Democracies: An Emerging Paradigm”, Milbank Quarterly, 73, 339-372.

Cooper, W.W. \& L.M. Seiford \& K. Tone (2002), Data Envelopment Analysis - A Comprehensive Text with Models, Applications, References and DEA-Solver Software, Kluwer Academic Publishers, USA.

Cooper, W.W. \& L.M. Seiford \& K. Tone (2006), Introduction to Data Envelopment Analysis and Its Uses With DEA-Solver Software and References, Springer Science+Business Media, USA.

Costa-Font, J. \& A. Rico (2006), "Devolution and The Interregional Inequalities In Health and Healthcare In Spain", Regional Studies, 40(8), 875-887.

Costa-Font, J. \& G. Turati (2018), "Regional Healthcare Decentralization in Unitary States: Equal Spending, Equal Satisfaction?”, Regional Studies, 52(7), 974-985.

Demirci, A. (2018), Teori ve Uygulamalarla Veri Zarflama Analizi, Gazi Kitapevi, Ankara-Turkey.

Giannoni, M. \& T. Hitiris (2002), “The Regional Impact of Health Care Expenditure: The Case of Italy", Applied Economics, 34(14), 1829-1836.

Harding A. \& A.S. Preker (2003), "A Conceptual Framework for the Organizational Reforms of Hospitals", in: A. Preker \& A. Harding (eds.), Innovations in Health Services Delivery: The Corporatization of Public Hospitals, World Bank, Washington D.C., 23-78.

Joumard, I. \& C. André \& C. Nicq \& O. Chatal (2008), "Health Status Determinants Lifestyle, Environment, Health Care Resources and Efficiency", OECD Economics Department Working Papers, No. 627, OECD Publishing.

Khushalani, J. \& Y.A. Ozcan (2017), “Are Hospitals Producing Quality Care Efficiently? An Analysis Using Dynamic Network Data Envelopment Analysis (DEA)", Socio-Economic Planning Sciences, 60, 15-23.

Küçük, Y.S \& B. Şahin (2015), "Kamu Hastane Birlikleri Uygulamasına İlişkin Sağlık Yöneticilerinin Görüşlerinin Değerlendirilmesi”, Hacettepe Sağllk Idaresi Dergisi, 18(2), 103-121.

Lamba, M. \& Y. Altan \& M. Aktel \& U. Kerman (2014), "Yeni Kamu Yönetimi Perspektifinden Türkiye'de Kamu Yönetimi Reformları: Genel Gerekçeler Üzerinden Bir İnceleme", SDÜ İ̈BF Dergisi, 19(3), 135-152.

lo Storto, C. \& A.G. Goncharuk (2017), "Efficiency vs Effectiveness: A Benchmarking Study on European Healthcare Systems", Economics and Sociology, 10(3), 102-115.

MoH (2003), Transformation in Health, <https://www.saglik.gov.tr/TR,11415/saglikta-donusumprogrami.html>, 25.01.2019. 
MoH (2014), Public Hospitals Statistical Yearbook -2014, Public Hospitals Authority, <https://khgm.saglik.gov.tr/Dosyalar/1b6f1adfa6c54b17ba5827a1ea1733c6.pdf>, 25.01.2019.

MoH (2017), Public Hospitals Statistical Report, <https://dosyamerkez.saglik.gov.tr/Eklenti/21853,kamu-hastaneleri-istatistik-raporu2017pdf.pdf?0>, 12.01.2019.

O’Donnell, O. (2007), “Access to Health Care in Developing Countries: Breaking Down Demand Side Barriers", Cad Saude Publica, 23, 2820-34.

Oates, W.E. (1972), Fiscal Federalism, New York: Harcourt Brace Jovanovich.

Osborne, D. \& T. Gaebler (1993), Reinventing Government, How the Entrepreneurial Spirit is Transforming the Public Sector, Plume, USA.

Ozcan, Y.A. \& J. Khushalani (2017), “Assessing Efficiency of Public Health and Medical Care Provision in OECD Countries After A Decade of Reform", Central European Journal of Operations Research, 25(2), 325-343.

Ozcan, Y.A. (2008), Health Care Benchmarking and Performance Evaluation - An Assessment Using Data Envelopment Analysis (DEA), (Edit. Hillier Fred), Springer Science+Business Media, USA.

Quadrado, L. \& H. Folmer \& S. Loman (2001), "Regional Inequality in The Provision of Health Care in Spain", Environment and Planning, 33(5), 783-798.

Ramanathan, R. (2003), An Introduction to Data Envelopment Analysis - A Tool for Performance Measurement, Sage Publications, New Delhi, India.

Şenol, O. \& M. Gençtürk (2017), "Veri Zarflama Analiziyle Kamu Hastaneleri Birliklerinde Verimlilik Analizi”, SDÜ Sosyal Bilimler Enstitüsü Dergisi, 4(29), 265-286.

Türkiye Kamu Hastaneleri Kurumu (2012), Birlik Değerlendirme El Kitabl, Ankara, <https://khgm.saglik.gov.tr/Dosyalar/4fe4e47c4c9c4a2e99ae675dcc3c0713.pdf〉, 25.01.2019.

WHO (2017), World Health Statistics 2017: Monitoring health for the SDGs, Part 2: Status of the Health -Related SDGs. 29:35.

<http://www.who.int/gho/publications/world_health_statistics/2017/EN_WHS2017_Part 2.pdf?ua=1>, 25.01.2019.

Wigley, S. \& A. Akkoyunlu-Wigley (2011), “The Impact of Regime Type on Health: Does Redistribution Explain Everything?", World Politics, 63(4), 647-77.

Yiğit, V. (2016), "Hastanelerde Teknik Verimlilik Analizi: Kamu Hastane Birliklerinde Bir Uygulama”, SDÜ Sağlık Bilimleri Enstitüsü Dergisi, 7(2), 9-15.

Zhong, H. (2010), "The Impact of Decentralization of Health Care Administration on Equity in Health and Health Care in Canada", International Journal of Health Care Finance and Economics, 10(3), 219-237. 